$\frac{\text { DE }}{\mathrm{G}} \stackrel{\text { DE GRUYTER }}{\text { OPEN }}$

\title{
Transparency in ECONOMic AND Political DECISION-MAKING: THE IDENTIFICATION OF SUNSHINE RULES FOR TRANSPARENT LOBBYING
}

\author{
Š́rka Laboutková $^{1}$, Petr Vymětal ${ }^{2}$
}

\begin{abstract}
Lobbying transparency seems to have been a challenging topic for nearly a decade. For the purposes of the article, the authors focus on a contextual analysis of rules and measures that offers both a broad as well as comprehensive view of the required transparency of lobbying activities and the environment in which decisions are made. In this regard, focusing on the sunshine principles/sunshine rules (not purely limited to laws) provides a grasp of the whole issue in a broader context. From a methodological point of view, the exploratory approach was chosen and the coding procedure is mostly dichotomous. As a result, seven key areas with 70 indicators have been identified in terms of transparency of lobbying and decision-making.
\end{abstract}

\section{Keywords}

Transparency, Lobbying, Decision-Making, Indicator

\section{Introduction}

The concept of transparency has become a central issue in the economic policy debate in recent years. Economic researchers solve and analyze transparency from many points of view, e.g. policy transparency (Sweeney, 2013; Geraats, 2009, 2013; Begg, 2006; Wehner and de Renzio, 2013), institutional, market and regulatory transparency (Wadensjö, 2015, Friberg, 2015, Cuervo-Cazurra, 2008), and corporate transparency (Hultén, Vanyushyng, 2010; Bushman, Smith, 2003, MacKay, 2015). Transparency is a prerequisite for the accountability of public officials and the legitimacy of decisions taken. Opacity provides some insulation against being accused of acting in an interest other than the public interest,

\footnotetext{
${ }^{1}$ Department of Economics, Faculty of Economics, Technical University of Liberec, Studentská 1402/2, 46117 Liberec 1, Czech Republic, E-mail: sarka.laboutkova@tul.cz.

${ }^{2}$ Department of Political Science, Faculty of International Relations, University of Economics in Prague, W. Churchill Sq. 4, 13067 Prague 3, Czech Republic. E-mail: petr.vymetal@ vse.cz.
} 
and also provides the opportunity for special interests to act in their own favor with greater influence. A high level of transparency in the political process is required (Lauth, 2016: 610). On the other hand, modern liberal systems are characterized by the existence of diverse interests that often compete with each other. Promoting individual or group interests is legitimate. One of the activities to promote interests is lobbying. The problem of a lack of transparent lobbying is closely related to increased inequality of access to public decision-making for voices representative of a wide range of interests. Equality of access is important in enabling decision makers to act and take decisions impartially, fairly and without discrimination. Thus, it is possible to reach a similar conclusion about the necessity of transparency for strengthening the legitimacy of decision-making through acting (including lobbying and interest representation) of citizens/civil society groups/interest groups in the political process.

There are several ways to approach the lobbying issue. The most common is to deal with regulation and rules - there are various rules and measures that might be introduced in the case of lobbying. This variability is shaped by the different reasons for which rules for lobbying are discussed and/or were introduced. In other words, the purpose of lobbying regulations is the result of several achievements: (1) restrictions on lobbying to reduce its intensity; (2) the fight against the risks of its intersection with corruption; (3) the introduction of transparency into lobbying practices and thus an opening up of the political process to external actors; (4) and the recognition of lobbying as a legitimate and useful part of the political process (Vargovčíková, 2011). For the purposes of our article, attention is focused on a contextual analysis of rules and measures, which meet in particular the third goal, with secondary impact on the second and fourth goal. The present paper's objective is to develop the third category of transparency lobbying measures. In our previous work, we have already proposed the first two groups of indicators (Vymětal, 2017, forthcoming; Laboutková, Vymětal, 2017, forthcoming). This third category of issues not only complements the first two, but de facto offers a wider and more comprehensive view on the required transparency of lobbying activities and the environment in which decisions are made. In this regard, focusing on the sunshine principles/sunshine rules (not purely limited to laws) aimed mostly at politics (politicians and public office holders especially) and related to lobbying and decision-making provides a grasp of the whole issue in a broader context.

Countries basically focus on the lobbying issue in only a narrow scope and understand regulation only as rules for lobbyists. But this is not the whole picture when it comes to lobbying. Our approach pays attention to other possible ways to support the transparency of lobbying and how to shed light on lobbying activities. We argue for transparency in lobbying - both to describe it as well as to derive a well-operating "model" - we do not have to take a single black and white picture - we rather take more pictures from different perspectives, with different lenses and in different arrangements and different composition to reconstruct the color (i.e. the real world) of lobbying. To see the rules for lobbying that are shaping the real actor's behavior is interesting and important, but the main idea is a little lost - lobbying tries to influence decisions and should be framed in a broader and wider angle. 
From a methodological point of view, the exploratory approach was chosen - the authors have no ambition to create indicators measured in numbers, but rather a qualitative content of indicators was chosen. The purpose is not to derive a single or limited number of indicators, but to operationalize and propose a coherent set of indicators that can describe the qualitative differences in selected aspects of transparency of lobbying rather than simply offer a non-committal single term quality of transparency in lobbying. For that reason, we very often use binominal values (yes-no) and in some cases we ask for numbers (if available) or written answers beyond the proposed list of answers.

\section{Recent approaches and research on lobbying transparency}

Lobbying transparency seems to have been a challenging topic for nearly a decade. There are a variety of recommendations, documents and discussions about the main principles and specific tools designed for both the lobbying regulation that would potentially subsequently have a boosting effect on lobbying transparency. Very often those approaches are understood as leveling the playing field for fair lobbying, and moreover also in respect of a broader scope - leveling the playing field of the decision-making process. Standards and measures widely discussed in the literature highlighting "good practice" (or "good governance") are based on the right to information and participation, effective control and supervision and open government, and are summarized in Table 1. The problem is no such recommendation specifically addresses any ex-post evaluation of the transparency of rules on lobbying, the transparency of lobbying activities, or transparency in decision-making.

Table 1: Summary of standards and measurements for transparent lobbying

\begin{tabular}{|c|c|c|}
\hline $\begin{array}{l}\text { International } \\
\text { organizations }\end{array}$ & Document & $\begin{array}{l}\text { Standards and measurements for } \\
\text { transparent lobbying }\end{array}$ \\
\hline OECD (2010) & $\begin{array}{l}10 \text { Principles for } \\
\text { Transparency and Integrity in } \\
\text { Lobbying }\end{array}$ & $\begin{array}{l}\text { - Building an effective and fair fra- } \\
\text { mework for openness and access } \\
\text { - Enhancing transparency } \\
\text { - Fostering a culture of integrity } \\
\text { - Mechanisms for effective implemen- } \\
\text { tation, compliance and review }\end{array}$ \\
\hline $\begin{array}{l}\text { Access Info } \\
\text { Europe, Open } \\
\text { Knowledge, } \\
\text { Sunlight } \\
\text { Foundation, } \\
\text { Transparency } \\
\text { International } \\
\text { (2015) }\end{array}$ & $\begin{array}{l}\text { International Standards for } \\
\text { Lobbying Regulation: } \\
\text { Towards greater transparency, } \\
\text { integrity and participation }\end{array}$ & $\begin{array}{l}\text { - Regulatory scope } \\
\text { - Transparency } \\
\text { - Integrity } \\
\text { - Participation \& Access } \\
\text { - Oversight, Management and sanctions } \\
\text { - Regulatory framework design }\end{array}$ \\
\hline $\begin{array}{l}\text { Access Info Europe } \\
\text { (2015) }\end{array}$ & $\begin{array}{l}\text { Lobbying Transparency via } \\
\text { the Right to Information }\end{array}$ & $\begin{array}{l}\text { - Equal access to information } \\
\text { - Right to information about lobbying } \\
\text { - Conflict of Interest, Codes of Conduct } \\
\text { and revolving door controls }\end{array}$ \\
\hline
\end{tabular}


Šárka Laboutková, Petr Vymětal: Transparency in Economic and Political Decision-Making: The Identification of Sunshine Rules for Transparent Lobbying

\begin{tabular}{|c|c|c|}
\hline $\begin{array}{l}\text { International } \\
\text { organizations }\end{array}$ & Document & $\begin{array}{l}\text { Standards and measurements for } \\
\text { transparent lobbying }\end{array}$ \\
\hline $\begin{array}{l}\text { Transparency } \\
\text { International } \\
(2015)\end{array}$ & $\begin{array}{l}\text { Lobbying in Europe: Hidden } \\
\text { Influence, Privileged Access }\end{array}$ & $\begin{array}{l}\text { - Transparency } \\
\text { - Integrity } \\
\text { - Equality of Access }\end{array}$ \\
\hline $\begin{array}{l}\text { Council of Europe } \\
\text { (2017) }\end{array}$ & $\begin{array}{l}\text { Recommendation } \\
\mathrm{CM} / \operatorname{Rec}(2017) 2 \text { of the } \\
\text { Committee of Ministers to } \\
\text { member States on the legal } \\
\text { regulation of lobbying } \\
\text { activities in the context of } \\
\text { public decision-making }\end{array}$ & $\begin{array}{l}\text { - Regulatory scope } \\
\text { - Freedom of expression, political acti- } \\
\text { vities and participation in public life } \\
\text { - Transparency } \\
\text { - Standards of behavior } \\
\text { - Public registers of lobbyists } \\
\text { - Sanctions } \\
\text { - Oversight bodies } \\
\text { - Sanctions } \\
\text { - Public sector integrity }\end{array}$ \\
\hline
\end{tabular}

Source: AIE (2015), AIE et al. (2015), CoE (2017), OECD (2010), TI (2015)

Thus, such variety of measures and rules for lobbying in place is for a good reason, which can be simplified as the experience that jurisdictions focus on and select different aspects, different problems and characteristics of lobbying. When it comes to rules only, the key differences can be identified as follows. First, for effective regulation, systematic regulation should be introduced. And basically, they can have the form of legal rules (hard rules) as well as the form of self-regulatory measures (Codes of Ethics, Codes of Conduct, Codes of Behavior). Second, for vibrant regulation, both sides of lobbying activities shall be covered - the direct rules aimed at main actors (i.e. lobbyists) and indirect rules for the other side of lobbying (i.e. the targets of lobbying - both politicians and civil servants). Third, the rules for lobbying are not covered by only a single bill; rather, they are a series of complementary legislation (legal provisions), internal and procedural rules (system arrangement) and institutional mechanisms (as distinguished, e.g. by TI UK (2015)). However, to build strong rules that meet the requirement of transparency and efficiency for all subjects in the lobbying industry is not easy, but it is possible. Current regulatory approaches do not always take this route - there are various measures introduced to somehow deal (directly or indirectly) with lobbying, but they are poorly linked with each other (isolated measures) and a systemic approach is lacking. A linkage between selective and narrowly aimed rules in the light of a systemic approach to lobbying regulation is needed. Fourth, effective control of lobbying activities shall be independent and shall be under the public scrutiny.

There are various approaches for how to regulate and classify lobbying rules (see Kalninš (2005), Griffith (2008) and others). The first contribution in this area is the work of Opheim (1991), who created the measures of the rigor of lobbying laws at the US state level. This measurement indicates the legislative independence and accountability from interest group pressure (Opheim, 1991: 405). She built her indicators on three key dimensions: the definition of a lobbyist, the frequency and quality of disclosure of personal and financial information and the enforcement of the regulation. A similar approach was introduced by 
Newmark (2005), who revised Opheim's measures. He included elements of how lobbying is defined in the regulation, what information lobbyists have to disclose and what activities pursued by lobbyists are prohibited by the law, but he did not include any context related to the enforcement of lobbying laws. The most frequently used schema for evaluation was developed by the Centre for Public Integrity in 2003 when it published a report and methodology for evaluating the influence of legislators (CPI 2003). The CPI index only evaluates existing rules on lobbying and lobbyists that are explicitly expressed in "hard" forms of regulation - acts and bills (statutory rules) especially (Laboutková, Vymětal, 2017).

Chari, Hogan (2006), Chari et al. (2010) provided a global comparative analysis of the robustness of lobbying laws. They took the methodology of the CPI index and created eight groups of categories: definition of lobbyists, definition of targets of lobbying, rules on registration, spending disclosure, electronic filing, public access to list of lobbyists, enforcement of rules, and revolving door provision. As a result, according to the scores they classified countries' lobbying regulation robustness into three groups (lowly regulated, medium regulated, and highly regulated systems).

Other aspects of lobbying rules - the indirect ones especially - and of lobbying activities are not covered. Holman and Luneburg (2012) provide a theoretical classification of regulated systems. Their items also include the definition of lobbying, the disclosure requirements and enforcement of the rules and also notice whether the regulation is mandatory or voluntary, whether or not the rules include the presence of codes of conduct for lobbyists and whether or not some interest groups are exempt from the rules (Crepaz and Chari, 2017).

The main weakness of the current approaches is that the main literature deals with laws in particular. In other words, so far, the process of explicit direct measuring of the transparency of lobbying remains unsolvable until lobbying is regulated at the level of jurisdiction. However, transparent lobbying exceeds the efficiency of a single law: it should be part and package of a wider approach to governance, based on the principles of openness, transparency, participation and disclosure. There are a number of factors (besides regulation focused on lobbying activities) that contribute to the transparency of lobbying: arrangements for the funding of political parties, laws on conflict of interests (including the so-called practice of the "revolving door"), legislative footprint, the statements of officials and politicians, etc.

There is no evaluation of the transparency of lobbying rules in terms of the decision-making process, or more precisely what provisions supporting the transparency of decision-makers have to be taken into account when speaking about the transparency of lobbying in terms of decision-making. The authors' aim is to overcome those deficiencies in the current research. For context, we propose a new design of catalogue on lobbying transparency that aims to evaluate lobbying in the broader scope. 


\section{Catalogue of lobbying transparency as a new, more complex approach in terms of decision-making}

As presented above, the paper develops the former methodological proposal of evaluating transparency in lobbying (Laboutková, Vymětal, 2017), where the category of "lobbyists" was only one among four categories and focuses on rules for the active actors of influence. Aggregated data on each category are shown in Table 2 that demarcate the basic conceptual empirical framework for the following development-specific indicators.

Table 2: Main categories on lobbyists' transparency

\begin{tabular}{|c|c|}
\hline Category & Data/information \\
\hline Lobbyists & $\begin{array}{l}\text { Register } \\
\text { Codes of Conduct } \\
\text { Disclosure of activities } \\
\text { Open calendars }\end{array}$ \\
\hline Targets of lobbying & $\begin{array}{l}\text { Codes of Conduct } \\
\text { Revolving doors } \\
\text { Conflict of interests } \\
\text { Disclosures of politicians/senior public employees } \\
\text { Appointment diaries }\end{array}$ \\
\hline $\begin{array}{l}\text { Sunshine principles / } \\
\text { Sunshine rules }\end{array}$ & $\begin{array}{l}\text { Rules on legislative process } \\
\text { Rules on decision-making } \\
\text { Rules on consultations } \\
\text { Legislative footprint } \\
\text { Open Government Data } \\
\text { Political parties funding } \\
\text { Freedom of information }\end{array}$ \\
\hline Monitoring and sanctioning & Sanctions \\
\hline
\end{tabular}

Source: Laboutková, Vymětal (2017), author's own changes

In each area, we can identify at least one source of information that can be used for the subsequent determination of indicators of transparency of lobbying. Until now, we have developed the category of "lobbyists" and "targets of lobbying".

The main goal of this chapter is to propose relevant criteria and indicators able to monitor provisions and measures labeled as "sunshine principles" and/or "sunshine rules" that can be used for evaluating the transparency of lobbying linked to decision-making.

The sunshine rules are a much broader matrix of issues; we therefore we have to link them more to lobbying and decision-making. Sunshine principles definitely limit the space for activities and also demarcate the playing field in terms of lobbying as well as decision-making. From this perspective, sunshine principles have two aspects - they are the framework for activities and limit other actors' behavior (setting the quality for others' activities), and at the same time they themselves formulate a level of quality. Fortunately, both aspects in our research lead to the same goal - transparency. 
In the following text, we propose seven relevant areas that, in our opinion, ultimately influence transparency in lobbying in terms of decision-making.

The first area is connected with the creation, negotiation and making of decisions during the whole legislative process. Although there are differences in the political system of countries, we do not limit the legislative process to only the parliamentary phase - we were naturally forced to extend it to the whole process, including the very beginning of the process (the initiation of drafts) and therefore logically include all stakeholders who can start a legislative process. On the other hand, it is true that a majority of the indicators proposed are connected with passing the law through the parliament (committees, deadlines, etc.). We do not differentiate between a new bill and/or the amendment or the process of suspension or cancelling a bill.

Table 3: Rules on legislative process

\begin{tabular}{|c|c|c|}
\hline & Indicator & Answer \\
\hline 1 & Who has the legislative initiative: & $\begin{array}{l}\text { Member of Parliament; Group of } \\
\text { MPs; Senator; Senate; } \\
\text { President/King; Government; } \\
\text { Ministers; Regions; Municipalities; } \\
\text { Citizens; Other - specify }\end{array}$ \\
\hline 2 & $\begin{array}{l}\text { Which document set essential rules for legislative } \\
\text { process at the governmental level? }\end{array}$ & $\begin{array}{c}\text { Constitution; Specific bill; } \\
\text { Governmental Rules of Procedures; } \\
\text { Other - specify }\end{array}$ \\
\hline 3 & $\begin{array}{l}\text { Which document set essential rules for legislative } \\
\text { process at the parliamentary level? }\end{array}$ & $\begin{array}{c}\text { Constitution; Special bill; } \\
\text { Parliamentary Rules of Procedures; } \\
\text { Other - specify }\end{array}$ \\
\hline 4 & $\begin{array}{l}\text { Which document set essential rules for initiation of } \\
\text { legislation and legislative process for other subjects? }\end{array}$ & $\begin{array}{l}\text { Constitution; Special bill; Rules of } \\
\text { Procedures; Other - specify }\end{array}$ \\
\hline 5 & $\begin{array}{l}\text { Can interest groups influence the content of the law } \\
\text { and the subjects holding decision-making power } \\
\text { during the law-making and decision-making of the } \\
\text { bill? }\end{array}$ & yes / no \\
\hline 6 & $\begin{array}{l}\text { Does Government keep updated list of planned } \\
\text { legislative work / Bulletin of planned legislative } \\
\text { work (not the Government Program Statement? }\end{array}$ & yes / no \\
\hline 7 & $\begin{array}{l}\text { Can the public follow the process of creating and } \\
\text { passing a piece of legislation at the level of } \\
\text { Parliament (online publicly available records of } \\
\text { phases legislative process)? }\end{array}$ & yes / no \\
\hline 8 & $\begin{array}{l}\text { Can citizens visit the public hearings of } \\
\text { Parliamentary Committees, and/or are there publicly } \\
\text { available records of Parliamentary Committees } \\
\text { meetings? }\end{array}$ & yes / no \\
\hline
\end{tabular}

Continued on next page 

Decision-Making: The Identification of Sunshine Rules for Transparent Lobbying

\begin{tabular}{|c|l|c|}
\hline \multicolumn{1}{|c|}{ Indicator } & Answer \\
\hline 9 & $\begin{array}{l}\text { Can the public follow the process of creating and } \\
\text { passing a piece of legislation at the level of } \\
\text { Government (if the Government can initiate the } \\
\text { law-making process) }\end{array}$ & yes / no \\
\hline 10 & $\begin{array}{l}\text { Who can propose an amendment to the bills in the } \\
\text { Parliament? }\end{array}$ & $\begin{array}{c}\text { One MP; Group of MPs (number); } \\
\text { party/fraction }\end{array}$ \\
\hline 11 & $\begin{array}{l}\text { Is there a possibility to propose (wild-)rider to the } \\
\text { passing piece of legislation? }\end{array}$ & yes / no \\
\hline 12 & $\begin{array}{l}\text { Who can propose a (wild-)rider to the passing piece } \\
\text { of legislation? }\end{array}$ & $\begin{array}{c}\text { One MP; Group of MPs (number); } \\
\text { party/fraction }\end{array}$ \\
\hline 13 & $\begin{array}{l}\text { Is there a mandatory requirement to propose an } \\
\text { amendment in written form? }\end{array}$ & yes / no \\
\hline 14 & $\begin{array}{l}\text { Is there RIA regularly conducted (at least in the case } \\
\text { of new proposed bills) }\end{array}$ & $\begin{array}{l}\text { yes / no } \\
\text { of new proposed bills) }\end{array}$ \\
\hline 15 & $\begin{array}{l}\text { Is there CIA regularly conducted (at least in the case } \\
\text { of }\end{array}$ & $\begin{array}{l}\text { What is the standard deadline between first and } \\
\text { second reading of the bill? }\end{array}$ \\
\hline 17 & $\begin{array}{l}\text { What is the standard deadline between second and } \\
\text { third reading of the bill? }\end{array}$ & Days \\
\hline
\end{tabular}

Source: author's own construction

As lobbying is often not linked with legislation, the second area of indicators is primarily aimed at the decisions taken at the governmental and/or administrative level (civil servants) in the case of measures, policies, state contracts, subsidies, programs, projects, grants, etc.

Table 4: Rules on decision-making process

\begin{tabular}{|c|l|c|}
\hline & \multicolumn{1}{|c|}{ Indicator } & Answer \\
\hline 1 & $\begin{array}{l}\text { Which documents set essential rules for } \\
\text { decision-making process at the governmental level? }\end{array}$ & List of documents \\
\hline 2 & $\begin{array}{l}\text { Publish the Government and/or Ministries position } \\
\text { to the individual measure proposals? }\end{array}$ & yes / no \\
\hline 3 & $\begin{array}{l}\text { Are there records from the Governmental meetings } \\
\text { about how the members voted on proposals? }\end{array}$ & yes / no \\
\hline 4 & $\begin{array}{l}\text { Can the public follow the process of } \\
\text { decision-making (online publicly available system)? }\end{array}$ & yes / no \\
\hline 5 & $\begin{array}{l}\text { Are the comments of Ministries and external } \\
\text { subjects (mandatory and/or voluntary subjects } \\
\text { commenting the proposals) available to the public } \\
\text { before the voting/final decision? }\end{array}$ & yes / no \\
\hline 6 & $\begin{array}{l}\text { Can the public approach the whole process of } \\
\text { decision-making at the governmental level ex-post? }\end{array}$ & \\
\hline
\end{tabular}

Source: author's own construction 
The third area of indicators specifically develops the organized information exchange between the government and civil servants on the one hand, and the interest groups and relevant stakeholders on the other. This issue is mostly connected with basic rules designed for the governmental level only.

Table 5: Rules on consultations with the public

\begin{tabular}{|c|l|c|}
\hline & \multicolumn{1}{|c|}{ Indicator } & Answer \\
\hline 1 & $\begin{array}{l}\text { Does Government initiate public consultations with } \\
\text { interest groups/citizens to the proposed bills, } \\
\text { policies, measures, strategies etc.? }\end{array}$ & yes / no \\
\hline 2 & $\begin{array}{l}\text { Are there any rules for consultation process in } \\
\text { place? }\end{array}$ & yes / no \\
\hline 3 & $\begin{array}{l}\text { How the public can get information about new and } \\
\text { running public consultations? }\end{array}$ & $\begin{array}{l}\text { Describe the manner (e.g. Bulletin, } \\
\text { web pages, direct invitation?) }\end{array}$ \\
\hline 4 & $\begin{array}{l}\text { What subjects are allowed to participate in public } \\
\text { consultancies? }\end{array}$ & Types of subjects \\
\hline 5 & $\begin{array}{l}\text { Is there any minimal time period for each } \\
\text { consultation? }\end{array}$ & yes / no \\
\hline 6 & $\begin{array}{l}\text { In which form are the consultancies organized? } \\
\text { (meetings); individual; group, etc. }\end{array}$ \\
\hline 7 & $\begin{array}{l}\text { Is there any list of participants of public } \\
\text { consultations publicly available? }\end{array}$ & yes / no \\
\hline 8 & $\begin{array}{l}\text { Is there publicly available any record of public } \\
\text { consultation? }\end{array}$ & $\begin{array}{l}\text { yes / no } \\
\text { meetings conducted in regards of public } \\
\text { consultancies? }\end{array}$ \\
\hline 9 & $\begin{array}{l}\text { Are politicians and POHs obliged to publish a list of } \\
\text { meetings conducted during public consultancies } \\
\text { with lobbyists and representatives of interest } \\
\text { groups? }\end{array}$ & yes / no \\
\hline
\end{tabular}

Source: author's own construction

When it comes to the legislative process, the so-called legislative footprint that is the fourth area of indicators is rising in popularity. The footprint includes the names of those who influenced the particular piece of legislation; that same information, on who participated in negotiations and who proposed or obstructed changes, can also be used in other areas, e.g. measures, policies, etc. 
Table 6: Legislative footprint

\begin{tabular}{|l|l|c|}
\hline & \multicolumn{1}{|c|}{ Indicator } & Answer \\
\hline 1 & $\begin{array}{l}\text { Is there a mandatory requirement to keep a list of } \\
\text { entities and individuals participating on the process } \\
\text { of creating and passing a piece of legislation? }\end{array}$ & yes / no \\
\hline 2 & $\begin{array}{l}\text { Is there a mandatory requirement to publish a list of } \\
\text { entities and individuals participating on the process } \\
\text { of creating and passing a piece of legislation before } \\
\text { the final voting in the Parliament (or at least once } \\
\text { the legislative process is finished)? }\end{array}$ & yes / no \\
\hline 3 & $\begin{array}{l}\text { Is there any publicly available list of entities and } \\
\text { individuals, which participated Parliamentary } \\
\text { committee hearings? }\end{array}$ & yes / no \\
\hline 4 & $\begin{array}{l}\text { Is there obligatory requirement to publish list of } \\
\text { entities and individuals, which participated during } \\
\text { the governmental decision-making process? }\end{array}$ & yes / no \\
\hline 5 & $\begin{array}{l}\text { Are entities and individuals required to disclose } \\
\text { information about the interest represented? }\end{array}$ & yes / no \\
\hline 6 & $\begin{array}{l}\text { Is there information about whose interest was } \\
\text { represented (namely the clients of } \\
\text { professional/contracted lobbyists)? }\end{array}$ \\
\hline
\end{tabular}

Source: author's own construction

More or less, the above-mentioned areas suppose that, fifth, there is a system for publishing information from the public authorities. Quite recently, governments jointly created the Open Government Project to publish and structure data on selected issues. Unfortunately, there is a single issue and it is a starting point that can be one day be extended in a specific way on decision-making, including some data on lobbying activities.

Table 7: Open government data

\begin{tabular}{|c|l|c|}
\hline & \multicolumn{1}{|c|}{ Indicator } & Answer \\
\hline 1 & $\begin{array}{l}\text { Is there any strategic and/or conceptual long-term } \\
\text { governmental document on Open data? }\end{array}$ & yes / no \\
\hline 2 & Are all public data made available? & yes / no \\
\hline 3 & $\begin{array}{l}\text { Are data available to anyone with no requirement of } \\
\text { registration? }\end{array}$ & yes / no \\
\hline 4 & Are data published according to an "open license"? & yes / no \\
\hline 5 & $\begin{array}{l}\text { Are published data up-to-date (without undue } \\
\text { delay)? }\end{array}$ & yes / no \\
\hline 6 & Is there any catalogue of open data? & $\begin{array}{c}\text { Scanned documents in PDF; } \\
\text { machine-readable structured data; } \\
\text { Open formats; universal identifiers; } \\
\text { interconnected data (LOD) }\end{array}$ \\
\hline 7 & In which degree of openness are the data published?
\end{tabular}




\begin{tabular}{|c|l|c|}
\hline & \multicolumn{1}{|c|}{ Indicator } & Answer \\
\hline 8 & $\begin{array}{l}\text { Which type of data / datasets in regard of lobbying } \\
\text { and decision-making is published? }\end{array}$ & $\begin{array}{c}\text { list of datasets } \\
\text { externally / no }\end{array}$ \\
\hline 9 & $\begin{array}{l}\text { Is possible to ask for more datasets within the } \\
\text { catalogue? }\end{array}$ & yes / no \\
\hline 10 & $\begin{array}{l}\text { Can users have comment on data directly in } \\
\text { catalogue? }\end{array}$ & $\begin{array}{l}\text { ls there any legislative regulation (and/or } \\
\text { governmental regulation) which provide public open } \\
\text { data of public authorities according the open data } \\
\text { standards? }\end{array}$ \\
\hline 12 & Is remote access to the open data available? & yes / no \\
\hline
\end{tabular}

Source: author's own construction

An issue that is narrowly connected to OGP, and is in fact its precondition, is, sixth, the rules for providing information according to the right to information. Variety across countries in this topic is significant in terms of the form and content of rules. Simply put, the right to information is mostly a complement to OGP - if the government and/or authorities do not provide datasets, often there is a chance to get information according to the right to information.

Table 8: Freedom of information

\begin{tabular}{|c|l|c|}
\hline \multicolumn{1}{|c|}{ Indicator } & Answer \\
\hline 1 & $\begin{array}{l}\text { Are there any rules (law, decree etc.) / policy for } \\
\text { replying requests on providing information? }\end{array}$ & yes / no \\
\hline 2 & $\begin{array}{l}\text { Who is not required to request information } \\
\text { according FoI? }\end{array}$ & yes / no \\
\hline 3 & $\begin{array}{l}\text { Is there any explicit list of information that usually } \\
\text { could not be provided (secret, personal. .)? }\end{array}$ & yes / no \\
\hline 4 & $\begin{array}{l}\text { Do the rules specify cases when it is in the overall } \\
\text { public interest that the information must be } \\
\text { disclosed (no matter if it harms someone private } \\
\text { interest)? }\end{array}$ & yes / no \\
\hline 5 & $\begin{array}{l}\text { Does the right for information bear important costs } \\
\text { for authorities to provide information? }\end{array}$ & yes / no \\
\hline 6 & $\begin{array}{l}\text { Are there increasing demands (financial, } \\
\text { administrative) placed on the applicant's request in } \\
\text { compliance with Fol? }\end{array}$ & yes / no \\
\hline 7 & $\begin{array}{l}\text { Are there any sanctions for breaching the obligation } \\
\text { to provide information in compliance with FoI? }\end{array}$ & in days \\
\hline 8 & What is the deadline for providing information? & yes / no \\
\hline 9 & Is the provided information relevant and complete? & yes / no \\
\hline 10 & $\begin{array}{l}\text { Do authorities proactively publish / provide some } \\
\text { type of frequently asked information? }\end{array}$ & \\
\hline
\end{tabular}

Source: author's own construction 
The last area that can significantly influence how decision-makers vote and decide is connected with political parties' funding and campaign financing. Through political funding interest groups, lobbyists and other third parties can have a voice in the decision-making process, either before or after an election. The rules - mostly based on legal regulation define (enclose) the space for allowed activities and to some extent create transparency on money entering the political arena.

Table 9: Political parties funding and campaign financing

\begin{tabular}{|c|c|c|}
\hline & Indicator & Answer \\
\hline 1 & Can legal persons finance political parties? & yes / no \\
\hline 2 & $\begin{array}{l}\text { Is there any ban on financing political parties by } \\
\text { interest groups and/or lobbyists in place? }\end{array}$ & yes / no \\
\hline 3 & $\begin{array}{l}\text { Are the donations provided to political parties } \\
\text { capped for both individuals and the legal persons? }\end{array}$ & $\begin{array}{c}\text { yes - how much is the cap set for } \\
\text { individuals and for legal persons / } \\
\text { no }\end{array}$ \\
\hline 4 & $\begin{array}{l}\text { Are political parties obliged to identify all donors } \\
\text { (both regular donations and campaign } \\
\text { contributions)? }\end{array}$ & yes / no \\
\hline 5 & $\begin{array}{l}\text { Is there any list of entities that political parties are } \\
\text { banned to accept any donation and non-financial } \\
\text { performance (state companies, foreign entities etc.)? }\end{array}$ & yes / no \\
\hline 6 & $\begin{array}{l}\text { Is there any ban in place on entities receiving public } \\
\text { money and public contract to finance political } \\
\text { parties and/or election campaigns)? }\end{array}$ & yes / no \\
\hline 7 & $\begin{array}{l}\text { Is there an independent authority supervising the } \\
\text { political parties funding? }\end{array}$ & yes / no \\
\hline 8 & $\begin{array}{l}\text { Is there cap set on maximum political parties } \\
\text { spending during campaigns? }\end{array}$ & yes / no \\
\hline 9 & $\begin{array}{l}\text { Is there an obligation for lobbyists to declare all } \\
\text { donations to the political parties (both financial and } \\
\text { non-financial) and candidates and/or all } \\
\text { contributions for campaigns (both financial and } \\
\text { non-financial)? }\end{array}$ & yes / no \\
\hline
\end{tabular}

Source: author's own construction

\section{Conclusion}

Although lobbying activity is currently increasing in the world and countries are trying to regulate lobbying activities in various ways, the question of the enforcement, effective rules and transparency of lobbying still attracts scholars' attention. In our previous research, we have dealt with lobbyists and the targets of lobbying and we have proposed a set of indicators that describes the transparency of both actors. But those describe only a part of the environment of lobbying. 
The present article's aim was to provide relevant criteria and indicators able to monitor provisions and measures labeled as "sunshine principles" and/or "sunshine rules" that can be used for evaluating the transparency of lobbying and represents a third part of the newly designed catalogue of lobbying transparency. This catalogue is aimed at evaluating lobbying in the broader scope. Seven relevant areas of sunshine principles/rules were suggested which ultimately influence transparency in lobbying in terms of decision-making. The first area is connected with the creation, negotiation and making of decisions during the whole legislative process. The second area of indicators primarily focuses on the decisions taken at the governmental and/or administrative level (civil servants). The third group of indicators specifically develops the organized information exchange between the government and civil servants on the one hand, and the interest groups and relevant stakeholders on the other. When it comes to the legislative process, the legislative footprint should be introduced and this represents the fourth area of indicators. The system of publishing information in their relevant political meaning by the public authorities and the right to require information by citizens and other entities represent the fifth and sixth groups. The last area deals with monetary interference in politics through the funding of political parties and campaign financing. The authors claim that this approach offers a more complex view on transparency in lobbying, because it includes linkages with other relevant issues of decision-making, rather than just dealing with lobbying rules.

To complete the picture of transparency in lobbying proposed in the catalogue, the last category remains a challenge for the authors' next work.

\section{Acknowledgements}

This paper has been elaborated as one of the outcomes of research projects supported by the Czech Science Foundation, project No. 16-11210S “Corruption Opportunity Space in the Czech Republic" and project No. 16-08786S "Impact of Transparency of Lobbying on Democratization and Its Consequences".

\section{References}

AIE et al. (2015). The International Standards for Lobbying Regulation. Access Info Europe, Open Knowledge, Sunlight Foundation, Transparency International. Retrieved May 30, 2017, from http://lobbyingtransparency.net/lobbyingtransparency.pdf.

AIE. (2015). Lobbying Transparency via the Right to Information. Access Info Europe. Retrieved May 30, 2017, from https://www.access-info.org/wp-content/uploads/Lobby_Transparency_via_RTI_26_June_2015.pdf.

Begg, I. (2006). Economic Policy and institutional transparency. In Oxelheim, L. (ed.). Transparency Corporate and Institutional Transparency for Economic Growth in Europe. Oxford: Elsevier.

Bushman, R. M., Smith, A. J. (2003). Transparency, financial accounting information and corporate governance. Economic Policy Review, 9, 65-87.

Chari, R., Hogan, J., Murphy, G. (2010). Regulating Lobbying: A Global Comparison. Manchester University Press. 
CoE. (2017). Recommendation of the Committee of Ministers to member States on the legal regulation of lobbying activities in the context of public decision making [online]. Strasbourgh: Council of Europe. Retrieved April 12, 2017, from https://search.coe.int/cm/ Pages/result_details.aspx?ObjectId=0900001680700a40.

CPI. (2003). [online] Hired Guns - Initial Report. Center for Public Integrity, 2003 [cit. 2016-09-30]. Available on https://www.publicintegrity.org/2003/05/15/5908/hired-gunsinitial-report.

Crepaz, M., Chari, R. (2017). Assessing the validity and reliability of measurements when evaluating public policy Journal of Public Policy, page 1 of 30 (C) Cambridge University Press.

Cuervo-Cazurra, A. (2008). The effectiveness of laws against bribery abroad. Journal of international business studies, 39, 803-822.

Friberg, R. (2015). Price transparency and market integration. In Forssbaeck, J.; Oxelheim, L. (eds.). The Oxford Handbook of Economic and Institutional Transparency. New York: Oxford University Press.

Geraats, P. M. (2009). Trends in monetary policy transparency. International Finance, 12(2), 235-268.

Geraats, P. M. (2013). Transparency: flexibility and macroeconomic stabilization. In Siklos, P. L.; Sturm, J. E. (eds.). Central bank Communication, Decision Making, and Governance: Issues, Challenges, and Case Studies. Cambridge, MA: MIT Press.

Griffith, G. (2008). "The Regulation of Lobbying.” Briefing Paper, no. 5. New South Wales Parliamentary Library Research Service, June 2008. Retrieved February 14, 2016, from https://www.parliament.nsw.gov.au/prod/parlment/publications.nsf/key/TheRegulationofLobbying/\$File/The+regulation+of+lobbying+No+5-2008+and+index.pdf.

Holman C. and Luneburg W. (2012) Lobbying and Transparency: A Comparative Analysis of Regulatory Reform. Interest Groups \& Advocacy, 1(1), 75-104.

Hultén, P., Vanyushyn, V. (2010). A new research paradigm to analyse the treats against fair competition in the global marketplace. Competitiveness Review, 20(2), 182-193.

Kalninš, A. (2005). Overestimation and venture survival: An empirical analysis of development commitments in international master franchising ventures. Journal of Economics \& Management Strategy, 14(4), 933-953.

Laboutková, Š. and P. Vymětal. (2017, forthcoming). Evaluation of Transparency of Lobbying as one of the Factors Reflecting the Institutional Quality. Paper presented at XXIX Annual conference of the Italian society of public economics, September 21-22, 2017, Catania.

Laboutková, Š. and P. Vymětal. (2017). Measures of Transparent Lobbying: How to Approach It and Evaluate It: A Preliminary Stage. In: Matějová, L. (ed.) Proceedings of the 21st International Conference Current Trends in Public Sector Research 2017. Brno: Masaryk University, 2017. pp. 50-57. ISSN 2336-1239. ISBN 978-80-210-8448-3. Retrieved May 30, 2017, from http://ctpsr.econ.muni.cz/wp-content/uploads/2017/01/Sborn\%C3\%ADk 2017_A5_tisk_obalka.pdf. 
Lauth, H. J. (2016). The internal relationship of the dimension of democracy: The relevance of trade-offs for measuring the quality of democracy. International Political Science Review, 37(5), 606-6017.

MacKay, P. (2015). Transparency of Corporate Risk Management and Performance. In Forssbaeck, J.; Oxelheim, L. (eds.). The Oxford handbook of Economic and institutional transparency. New York: Oxford University Press.

Newmark, A. J. (2005) Measuring State Legislative Lobbying Regulation, 1990-2003. State Politics \& Policy Quarterly, 5(2), 182-191.

OECD. (2010). The 10 Principles for Transparency and Integrity in Lobbying. Paris: OECD, 2010 (updated 2013). Retrieved May 30, 2017, from http://www.oecd.org/corruption/ethics/Lobbying-Brochure.pdf.

Opheim, C. (1991). Explaining the Differences in State Lobby Regulation. The Western Political Quarterly, 44(2), 405-421.

Sweeney, R. J. (2013). Constitutional transparency and constitutional changes. Working Paper, Georgetown University, Washington, DC.

TI. (2015). Lobbying in Europe: hidden influence, privileged access. Berlin: Transparency International. Retrieved May 30, 2017, from http://files.transparency.org/content/download/1909/12646/file/2015_LobbyingInEurope_EN.pdf.

Vargovčíková, J. (2011). Variace diskursivního pojetí lobbingu v České republice a implikace pro jeho regulaci. Politologická revue, 17(2), 75-98.

Vymětal, P. (2017, forthcoming). Transparency in Lobbying - the Key Aspects of Lobbyists' Activity. Paper presented at 13th International Conference Liberec Economic Forum 2017, September 11-13, 2017, TU Liberec.

Wadensjö, E. (2015). Labor market transparency. In Forssbaeck, J.; Oxelheim, L. (eds.). The Oxford handbook of Economic and institutional transparency. New York: Oxford University Press.

Wehner, J., de Renzio, P. (2013). Citizens, legislators, and executive disclosure: The political determinants of fiscal transparency. World Development, 41, 96-108. 